\section{En torno a los créditos de un filme}

José Carlos Huayhuaca
$A$ lgunos estudiantes de mi curso sobre apreciación cinematográfica consideran exagerada mi tajante negativa a permitirles ver una película ya empezada. "AAdmitirían ellos leer una novela carente de las dos o tres primeras páginas?", replico; y el argumento implícito en la analogía suele ser suficiente respecto de lo que llaman "la película propiamente dicha". Pero si aún se están proyectando los créditos, entonces se trataría de un mero capricho de mi parte.

No lo es si tomamos en cuenta que, en los mejores casos, también los créditos juegan un rol importante, por lo común generando determinada atmósfera, o poniéndonos en una suerte de sintonía con la onda del relato subsiguiente - ya sea a través de la música, de las a veces muy sofisticadas animaciones provistas por los titles designers o incluso del tipo y color de las letras articuladas con sus respectivos fondos-. Pero bastante más está en juego cuando los filmes tienen un prólogo, como es el caso —entre muchos- de Pulp fiction; o cuando los créditos van "sobre imágenes", como en el notable ejemplo de El silencio de los inocentes (Silence of the lambs, 1997, dirigida por Jonathan Demme). El caudal de (tácita) información que se nos da a lo largo de la presentación de esta película, puede parecer circunstancial en un primer momento; pero según avanza, o cuando ya ha terminado, gana relevancia retrospectivamente, enrique- 
ciendo de modo decisivo su significado. ¿Qué es lo que vemos mientras se suceden títulos, nombres y cargos?

\section{¿De qué huye (o adónde va) la agente Starling?}

Para la mirada del espectador distraído, que todavía conversa con su vecino de butaca o aprovecha para extraer los últimos pop corns de su bolsa, solo se trata de una chica que hace jogging a campo traviesa, hasta que un agente del FBI le dice que la buscan con urgencia, por lo que ella tiene que interrumpir su ejercicio e ir a la cita. Pero lo que ocurre en realidad, o lo que los espectadores atentos logramos registrar, aun "sin saberlo", es otra cosa, que descifraremos solo después.

Todo comienza con un fragmento de cielo gris y la copa de un árbol. La cámara desciende y descubrimos un bosque sumido en una densa neblina, de cuya hondura - más precisamente: de abajo y del fondo- emerge una jovencita que viene corriendo hasta la parte alta, adonde trepa con esfuerzo, mediante una soga: ¿qué ocurre, quién es, de dónde ha salido? La música refuerza esa sensación de incógnita pero también insinúa soledad y tristeza. A medida que la joven se nos acerca, la escuchamos jadear y vemos que su ropa está húmeda de sudor. En su semblante convergen la vulnerabilidad con una determinación que la hace sobre- ponerse a su propio cansancio y proseguir, a la carrera otra vez: ¿va hacia algo o más bien huye? (tengamos en cuenta que, en ese punto, la música incluye acentos como de amenaza o peligro).

No obstante lo casuales que lucen el buzo y las zapatillas de jogging de la chica, el "clima" suscitado por su actitud, por la música que se hace más dinámica, por el súbito apremio que cobra todo el ritmo del filme, por la cámara que de los amplios espacios iniciales pasa a opresivos close ups del rostro crispado y los pies que corren cada vez más de prisa; ese "clima" — digo_ no parece corresponder a un afán deportivo sino a algo más bien ominoso, remarcado por la bruma que obstruye el sendero siguiente, en el que ella se adentra con resolución. Pero cuando emerge de ahí, encuentra un obstáculo típico de campo de entrenamiento ( $j a h$, se trataba de eso!), el cual supera con solvencia aunque desplegando siempre mucha fuerza de voluntad, hasta detenerse de súbito al escuchar que la llaman a gritos. "Debe dejar sus ejercicios pues se le requiere con urgencia", le informa un hombre en cuya gorra figura una sigla que conocemos bien: FBI. Ahora ya todo está claro: era la joven recluta Clarice Starling, haciendo sus prácticas cotidianas.

Con estas nuevas luces orientándonos sobre lo que ocurre, además de la repentina presencia de otra luz — la del 
sol- filtrándose entre los árboles cuando creíamos estar en un día cubierto, vemos luego a diversos estudiantes que también se ejercitan, al costado de un edificio moderno cuyos bloques están unidos por un puente cubierto de lunas transparentes. La recluta lo cruza con diligencia, hasta llegar a un ascensor al que ingresan ocho o nueve hombres uniformados, entre quienes ella luce frágil y pequeña, pero no amilanada. Los créditos concluyen cuando la vemos ingresar a la sección de "Ciencias de la Conducta”, donde tiene su cita.

\section{La noche de los corderos inocentes}

Lo demás ya se conoce: allí le darán la misión de intentar que el famoso asesino serial Hannibal Lecter aporte su concurso para la captura del nuevo astro de esa escalofriante especialidad: Buffalo Bill, y de ese modo Clarice Starling se embarcará en la vertiginosa aventura suficientemente difundida por el célebre filme. Lo interesante es, repito, la nueva significación que adquiere el segmento arriba descrito, una vez que el relato entrega sus episodios, y cómo, a su turno, tal giro desplaza el núcleo semántico del filme: de thriller de acción donde convergen ilustres géneros como el policial y el terror, a estudio de caracteres o, mejor dicho, a una parábola psicológica, a la manera de ciertos cuentos de hadas. En efecto, al margen de los momentos centrales del filme, múltiples crímenes, peripecias de la pesquisa policial misma, instancias de ruidosa intervención con armas, espectaculares fugas, etcétera, ahora ganan protagonismo tanto los recuerdos de infancia que irrumpen por momentos en la conciencia de la joven, cuanto otra pesquisa "detectivesca": la que ejerce el psiquiatra Lecter en el orbe emocional de Clarice. Así, nos enteramos de modo explícito de algunas cosas, e implícitamente de otras.

En orfandad total a los diez años, Clarice sufre desde entonces el desamparo y la soledad correspondientes, por lo común, a esa trágica condición, aliviada únicamente por los dulces recuerdos y el ejemplo moral de su padre (honesto y valiente policía rural, cuya vida fue segada por un delincuente). Con la sola ayuda de tal brújula, enfrenta al mundo y, no obstante las asechanzas de que está lleno —-sobre todo si se carece de la protección de los padres, logra sobrevivir en él, aunque un episodio de su pasado la persigue como una pesadilla. Todavía niña, cierta noche fue despertada por quejidos lancinantes: en la granja de unos tíos con quienes vivía, unos corderos estaban siendo sacrificados en el establo. No lo pudo tolerar, trató vanamente de impedirlo y por último huyó con uno para salvarle la vida; pero el peso del animalito, el frío y el hambre, resultaron difíciles de resistir. Fue rescatada por agentes rurales y devuelta al hogar adoptivo, del cual eventualmente la 
expulsaron por aquella "mala" acción. Podemos imaginar una fractura, o siquiera una vacilación, en su sentimiento de lo correcto y lo incorrecto, y de ahí un ansia por aclarar, para sí, estas y otras perplejidades morales. Es fácil comprender que, años después, al encarar la adolescente el consabido dilema de elegir un oficio, el FBI se constituyera de modo natural en una alternativa plena de sentido: en tanto carrera profesional adecuada para una hija de policía, pero también en tanto modo de investigar sobre zonas oscuras de sí misma y el mundo, y aun de reencontrarse simbólicamente con el Padre (no en vano su mentor en el FBI tiene un porte similar al de su padre) y curar diversas heridas afectivas (como aquella expresada en el episodio de los dolientes corderos, cuya significación —no por difusa menos efectiva- se proyecta como una sombra sobre todo el filme, desde el título mismo).

Ahora volvamos a "leer" la secuencia de los créditos.

\section{Una niña perdida en el bosque}

Claro que no nos habíamos engañado: no se trataba simplemente de una recluta del FBI en el trance de hacer sus ejercicios de rutina al aire libre, sino - como lo sospechamos inconscientemente desde el principio- de una niña perdida en el bosque (situación análoga a la de Blancanieves, Caperucita
Roja, Hansel y Gretel y otras criaturas semejantes que pueblan nuestro sustrato mental). Todos los problemas de la situación previa de Clarice-niña están condensados en esa metáfora, así como su convicción de poder lidiar con ellos gracias a una actitud rectilínea y al esfuerzo personal. El brumoso bosque — setting inicial del filme, del que "surge" Clarice y donde comienza el relato- tiene universales y complejas significaciones que, provistos de un buen diccionario de símbolos, podríamos resumir así: el bosque es una matriz generadora de vida, pero es también un ámbito entreverado y peligroso; hunde sus raíces en el suelo pero alcanza o toca con sus copas la bóveda del cielo; es, en la síntesis de Francis Spufford, "un territorio denso, inculto, donde es difícil la orientación y donde el individuo aislado debe aprender por sí mismo a encontrar su camino; un territorio que representa, a la vez, el mundo exterior y el inconsciente dentro de uno".

Este sentido dual, intrínseco al bosque como arquetipo (¡he, Jung, viejo sabido!), da forma, desde el interior y de modo sistemático, a los avatares explícitos del filme.

Asistimos, así, a una dramaturgia de antagonismos subyacentes:

- El mundo de arriba versus el mundo de abajo (ella emerge de una hondonada con la ayuda, podría decirse, 
de la cuerda salvadora que le tiende el FBI, cuya aparición en la parte de arriba coincide con la de los rayos del sol; los asesinos seriales ya condenados están recluidos en una cárcel subterránea; la última víctima de Buffalo Bill, a quien Clarice acude a rescatar, está en una fosa).

- La claridad versus la tiniebla (el edificio del FBI es moderno y de lunas transparentes, mientras el lugar donde está encerrado Lecter es una suerte de "castillo gótico" lleno de galerías y de corredores recónditos; por su parte, la casa de Buffalo Bill es un ámbito de interiores cada vez más tenebrosos, que culminan en la oscuridad total cuando ocurre un apagón en el preciso clímax del filme).

- La ley y el orden versus la transgresión y el delito; la razón versus lo irracional —en suma- el FBI (con sus especialistas en "ciencias de la conducta") versus los asesinos seriales.
Clarice, criatura de la luz (ya desde su propio nombre), se adentra - por el mandato de su jefe/padre, pero también para probarse a sí misma- en las profundidades de lo oscuro.

Entre tales polos se debate heroicamente en su empeño, no solo de cumplir con una tarea específica: atrapar al asesino, sino para superar su propia situación de incertidumbre existencial, para salvar por fin al inocente cordero que hicieron sufrir en aquel triste episodio de su infancia, para reencontrar la brújula que perdió con la muerte de su padre, para volverse un adulto digno y autosuficiente. El silencio de los inocentes es un policial de terror, pero es también un rito de pasaje (según dirían los antropólogos) o la parábola de una venturosa iniciación en la vida, como los cuentos de hadas. Y las imágenes que discurren bajo los créditos del filme son la clave de esa profunda significación. 